\title{
Investment Opportunity Set Analysis as a Mediation of Influence of Capital Structure on Company Value with Economic Growth as a Moderating Variable
}

\author{
Yusna*, Sugeng Sulistiono \\ Accounting Department \\ State Polytechnic of Malang \\ Malang, Indonesia \\ *yusnapoltek@gmail.com, penkpoltek@gmail.com
}

\begin{abstract}
This study aims to examine and analyze (1) the indirect effect of capital structure on firm value through the investment opportunity set mediation, (2) the direct effect of capital structure on firm value which is moderated by economic growth. This research was conducted at manufacturing companies listed on the Indonesia Stock Exchange (IDX) with data from 2015 to 2018 . The data was collected using purposive sampling technique and the population was based on population criteria. The research sample companies are saturated or census samples and the number of research samples is 15 companies. The data analysis method is Path Analysis and Sobel Test which are used to test the investment opportunity set mediation variable. The results showed that the effect of capital structure on firm value was mediated significantly by IOS. Meanwhile, economic growth significantly moderates the effect of capital structure on firm value.
\end{abstract}

Keywords-investment opportunity set, capital structure, firm value and economic growth

\section{INTRODUCTION}

The company's financial decisions are management actions to manage fund sources and invest company funds. The investment funds are used for the company's operating activities and long-term investment activities. For public companies, management is the agent of the principal as the owner of the company. The purpose of managing company funds is to maximize company value. Sources of funding can use their own capital, debt or retained earnings. This funding decision becomes the investor's consideration regarding the financial risk that will be received. This condition affects investors' perceptions of the company. This will affect the stock price as well as illustrate the company's value. The decision to use certain types of funds to finance company investments also shapes investors' perceptions of future returns and risks.

Several studies on the relationship between capital structure and firm value were stated by Masulis [1], the results of his research show that changes in stock prices are positively related to changes in leverage, especially convertible senior security stocks. Fama and French showed that the tax effect on debt policy negatively affects firm value [2]. Miller's research on the effect of taxes on income as well as a signaling theory that describes the use of debt indicates company growth. Chen's research shows that debt is positively and significantly related to firm value for companies with low growth opportunity [3]. Meanwhile, the relationship between debt and firm value is not significant in high growth opportunities. Furthermore, Jirapon and Liu showed a significant positive relationship between the use of debt and firm value [4].

Ikbal, Sutrisno, and Djamhuri have discussed the effect of capital structure on firm value which shows that debt policy has a negative effect on firm value [5]. Efni's research shows that funding decisions do not have a significant direct effect on firm value [6]. Furthermore, Masidonda in his research showed that the effect of capital structure on firm value was significant positive on firm value [7]. Based on the research above, it is shown that the capital structure is measured using long term debt as part of long-term capital. The use of long-term debt is associated with long-term investment financing and this affects investors' perceptions of firm value.

Efni conducted a discussion of the effect of investment opportunity set on firm value which shows that investment decisions have a significant positive direct effect on firm value [6]. Yuliani in his dissertation showed that IOS had a significant positive effect on firm value [8]. Research by Hutchinson and Gul, on the effect of IOS on firm value with corporate governance as a moderating variable. The result of the research is that there is a negative relationship between growth (as measured by IOS) and firm value, this relationship is weakened by the moderating variable of corporate governance.

Hutchinson and Gul, conducted research on the effect of executive share options and investment opportunity sets on company performance [9]. The result of this research is that ROE has a significant positive relationship with IOS and total executive remuneration. IOS and share option plans have a 
significant positive relationship to company performance. The strengthening of the JCI in the Indonesian capital market shows that companies listed on the Indonesian stock exchange are experiencing growth, so that investors are interested in investing their funds in securities listed at PT. Indonesia stock exchange. This is related to the improving economic situation in Indonesia has a positive effect on all economic sectors. This situation affects the overall performance of the company and reflects an increase in firm value. Firm value is a central issue for investors in their investment decisions, because firm value provides an overview of the company's fundamental conditions and market situations that affect market players in the Indonesian capital market. Based on the research concept framework, theories and previous studies, the research hypothesis is structured as follows.

Hypothesis 1: IOS mediates the effect of capital structure in increasing firm value.

Hypothesis 2: Economic Growth moderates the effect of capital structure on firm value.

This research is important because it can provide information for company management. The results of this study can be used as a basis for corporate financial decisions. This information relates to variables that affect firm value. In addition, this information is useful for investors in making funding decisions and investment decisions that can affect company value.

This study aims to: 1) To test and analyze IOS in mediating the effect of capital structure on Firm Value, and 2) To test and analyze economic growth in moderating the effect of investment decisions on Firm Value.

\section{METHODS}

The research approach used is the positivist paradigm, which is a mainstream quantitative approach. Quantitative research uses secondary data as a result of documenting empirical phenomena that can be observed (observable), repeatable, measurable, testable and predictable. This research was conducted on research objects engaged in the manufacturing sector. The choice of research object is based on the needs of the research objectives being carried out. Furthermore, this research was carried out on companies listed on the Indonesia Stock Exchange. The number of companies registered was 485 companies engaged in various industrial sectors.

The research object is a manufacturing company listed on the Indonesia Stock Exchange. The study population is determined based on several population criteria, so that the study population can be determined. Sampling was done by purposive sampling, and the sample describes the characteristics of the population. The research period is 2015 to 2018 with 72 companies as samples, so the number of research data is 288 data.
Analysis Model for moderation variable

$$
\mathrm{Y}=\alpha+\beta 1 \mathrm{X} 1+\beta 2 \mathrm{X} 2 * \mathrm{EG}+\mathrm{e}
$$

The proxies used in this study are shown as follows:

- Capital structure (X1), is an exogenous variable measured by Debt to Equity Ratio (DER)

- Investment Opportunity Set (Y1), is an endogenous variable as a mediating variable as measured by market to book value of equity (MVE / BVE).

- Economic growth (M) is the rate of economic growth in the study period.

- Firm Value (Y2), is an endogenous variable measured by Tobin's Q ratio.

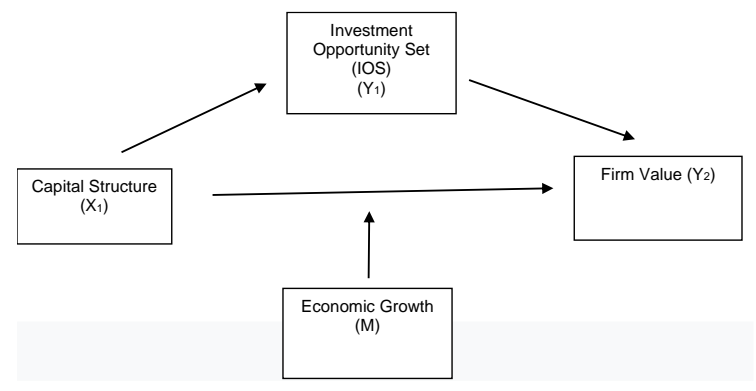

Fig. 1. Research model.

The tests carried out are: Designing the Path Analysis Model as part of the mediation test in accordance with the research model described above. Furthermore, hypothesis testing was held. The next step, testing the moderation model to prove the research hypothesis.

\section{RESULTS}

The influence between variables in this study is explained using Path Analysis. The strength of influence between variables is indicated by the strength of the path in the Path diagram. This includes the independent variables X1 (capital structure with DER proxy) and Y1 (IOS with proxy MVE / $\mathrm{BVE}$ ratio) and $\mathrm{Y} 2$ (company value with the proxy $\mathrm{Q}$ ratio). Based on the regression analysis, the path analysis includes the calculation of the direct effect between variables and the indirect effect involving the mediating variable. The calculation results are as follows:

\section{A. Regression Analysis}

Simultaneous regression calculations and partial regression using SPSS with $\mathrm{n}=288$ which includes the independent variables $\mathrm{X} 1$ (capital structure with the proxy DER) and Y1 (IOS with proxy MVE/BVE ratio) and Y2 (company value with the proxy Q-ratio). The calculation results are as follows table 1: 
TABLE I. SimUltanEOUS REGRESSION CALCUlations AND PARTIAL REGRESSION

\begin{tabular}{|c|c|c|}
\hline $\begin{array}{c}\text { Model Summary Table: } \\
\text { Predictor Capital Structure }\end{array}$ & $\begin{array}{ll}\begin{array}{l}\text { Adjusted } \\
\text { square }\end{array} & \mathrm{R} \\
\end{array}$ & 0,266 \\
\hline \multirow[t]{2}{*}{$\begin{array}{c}\text { Tabel Anova } \\
\text { Predictor: Capital Structure } \\
\text { Dependent variable: firm Value }\end{array}$} & Regression & $\begin{array}{l}\text { Significant } \\
0,000\end{array}$ \\
\hline & $\mathrm{F}$ & 24,192 \\
\hline $\begin{array}{c}\text { Coefficients: Model Capital } \\
\text { Structure } \\
\text { Dependent variable: firm Value }\end{array}$ & & $\begin{array}{l}\text { Significant } \\
0,000\end{array}$ \\
\hline $\begin{array}{l}\text { Model Summary Table: } \\
\text { Predictor DER }\end{array}$ & $\begin{array}{ll}\begin{array}{l}\text { Adjusted } \\
\text { square }\end{array} & \mathrm{R}\end{array}$ & 0,34 \\
\hline \multirow[t]{2}{*}{$\begin{array}{c}\text { Tabel Anova } \\
\text { Predictor: DER } \\
\text { Dependent variable: } \text { IOS }\end{array}$} & Regression & Sig 0,000 \\
\hline & $\mathrm{F}$ & 34,024 \\
\hline $\begin{array}{l}\text { Coefficients: Model DER } \\
\text { Dependent variable : IOS }\end{array}$ & & $\begin{array}{l}\text { Significant } \\
0,000\end{array}$ \\
\hline $\begin{array}{c}\text { Model Summary Table: } \\
\text { Predictor IOS }\end{array}$ & $\begin{array}{ll}\begin{array}{l}\text { Adjusted } \\
\text { square }\end{array} & \mathrm{R} \\
\end{array}$ & 0,94 \\
\hline \multirow[t]{2}{*}{$\begin{array}{c}\text { Tabel Anova } \\
\text { Predictor: IOS } \\
\text { Dependent variable: firm Value }\end{array}$} & Regression & $\begin{array}{l}\text { Significant } \\
0,000\end{array}$ \\
\hline & $\mathrm{F}$ & 1005,466 \\
\hline $\begin{array}{c}\text { Coefficients: Model IOS } \\
\text { Dependent variable : firm Value }\end{array}$ & & $\begin{array}{l}\text { Significant } \\
0,000\end{array}$ \\
\hline
\end{tabular}

\section{B. Path Calculation}

The path calculation is used to determine the strength of the paths shown in the path diagram. The path coefficient value is determined based on regression analysis between exogenous and endogenous variables. Regression analysis is used to measure the effect of (1) DER and DPR on MVE / BVE and (2) DER, DPR and MVE / BVE variables on Q ratio.

TABLE II. PATH COEFFICIENT OF DIRECT EFFECT OF RESEARCH VARIABLES

\begin{tabular}{|c|c|c|c|c|}
\hline No & $\begin{array}{c}\text { Direct Effect } \\
\text { between variables }\end{array}$ & $\begin{array}{c}\text { Path } \\
\text { coefficient }\end{array}$ & p-value & Conclusion \\
\hline 1. & $\begin{array}{l}\text { Direct Effect DER } \\
\left(\mathrm{X}_{1}\right) \text { to MVE/BVE } \\
\left(\mathrm{Y}_{1}\right) .\end{array}$ & 0,592 & 0.000 & Significant \\
\hline 2. & $\begin{array}{l}\text { Direct Effect DER } \\
\left(\mathrm{X}_{1}\right) \text { to Q-ratio }\left(\mathrm{Y}_{2}\right) .\end{array}$ & 0,527 & 0,000 & Significant \\
\hline 3. & $\begin{array}{lr}\text { Direct } & \text { Effect } \\
\text { MVE/BVE }\left(\mathrm{Y}_{1}\right) \text { to } \\
\text { Q-ratio }\left(\mathrm{Y}_{2}\right) .\end{array}$ & 0,970 & 0,000 & Significant \\
\hline
\end{tabular}

Information: $\alpha=0.05$

Based on Table 2, it is shown that:

- The effect of DER (X1) on MVE / BVE (Y1) is significant with a p-value of 0.000 .

- The effect of DER (X1) on Q ratio (Y2) is significant with a p-value of 0.000
- The effect of MVE / BE (Y1) on Q ratio (Y2) is significant with a p-value of 0.000

\section{Mediation Variable Test}

The indirect effect of research variables is the effect of capital structure (DER) on firm value ( $Q$ ratio) through the mediating variable IOS (MVE / BE). Testing the indirect effect using the Sobel Test. The Sobel Test is a mediating variable analysis tool that can be done by multiplying the coefficients [10]. In this research model, testing the indirect effect of the capital structure variable (DER) on firm value ( $Q$ ratio) through IOS (MVE / BE). The proof of this indirect effect is done by means of the Sobel Test, which shows the following calculations (table 3 and table 4).

TABLE III. CALCUlation OF SOBEL TEST

\begin{tabular}{|c|c|c|c|c|}
\hline \multirow[b]{2}{*}{\begin{tabular}{l|l}
$X$ & $A$
\end{tabular}} & Coefficient & Error & \multicolumn{2}{|c|}{ Square } \\
\hline & 3.6867 & 0.7496 & 13.5915 & 0.5618 \\
\hline \multirow[t]{5}{*}{ Z } & 0.3034 & 0.0111 & 0.0921 & 0.0001 \\
\hline & up & 1.1187 & & \\
\hline & Under & 0.2311 & & \\
\hline & Z-score & 4.8406 & & \\
\hline & conclusion & significant & & \\
\hline
\end{tabular}

TABLE IV. SOBEL TEST INDIRECT EFFECT DER (X1) TO Q RATIO (Y2) WITH MVE / BVE AS MEDIATION (Y1)

\begin{tabular}{|l|l|l|l|}
\hline No & \multicolumn{1}{|c|}{ Indirect effect } & Z-score & conclusion \\
\hline 1. & $\begin{array}{l}\text { Indirect effect of DER } \\
\text { (X1) on Q ratio (Y2) } \\
\text { through MVE/BVE (Y1) }\end{array}$ & 4,8406 & Significant \\
\hline
\end{tabular}

Therefore, the first hypothesis which states that IOS mediates the effect of capital structure in increasing firm value is proven.

\section{Moderation Variable Test}

The effect of capital structure and economic growth on firm value is carried out by performing regression testing. The dependent variable in this regression model is the variable of firm value, capital structure is the independent variable with a moderating variable of economic growth.

- The simultaneous effect of DER and EG variables on firm value is significant with $\operatorname{sig}=0.00$ with $\mathrm{R} 2=$ 0.939 .

- The effect of DER on firm value is significant with sig $=0.00$ with a regression coefficient $=0.970$.

- The effect of economic growth (EG) on firm value is not significant with sig $=0.774$ 
- The simultaneous effect of DER, DER * EG and EG variables on firm value is significant with sig $=0.00$ with $\mathrm{R} 2=0.243$

Therefore, the second hypothesis which states that economic growth moderates the effect of investment decisions on firm value is proven.

\section{DISCUSSION}

The results of proving first hypothesis indicate that IOS significantly mediates the effect of capital structure on firm value. The direct effect of capital structure on firm value is significant. IOS as a mediating variable that describes company growth affects firm value. In this case, the company's growth affects investors' perceptions on the stock exchange. Share price as an element of company value is affected by the company's capital structure and growth rate. The use of longterm debt in financing company investment and company growth is proven to affect firm value. This condition is reinforced by the effect of capital structure on IOS which is proven significant and the effect of IOS on firm value is also proven significant.

The results of the proof of second Hypothesis indicate that economic growth is proven to have a significant effect on firm value. This is reinforced by the significant influence of capital structure and IOS on firm value. Investor responses to economic growth lead to changes in stock prices. If the share price has increased, this reflects an increase in company value. This can indicate the role of economic growth which can strengthen or weaken the effect of investment decisions on firm value.

The influence of IOS has a significant effect on firm value. This shows that company growth has a direct effect on firm value and this illustrates that capital market players respond positively to IOS as a measure of company growth. The effect of capital structure on IOS is significant, this shows that the use of debt to finance company investment can be accepted by investors. The use of debt provides a signal that the company has good prospects in the future (signaling theory). The effect of capital structure on firm value occurs when mediated by IOS and this is indicated by the significant influence of IOS on firm value. This is reinforced by the significant effect of capital structure on firm value. Thus, this shows that investors assess the capital structure using debt to provide a good picture of the company's business prospects in the future.

\section{A. Suggestion}

Company management is expected to consider the optimal proportion of debt in the company's capital structure. Management actually thinks that increasing the amount of debt will increase profits (tax deductible expenses). In addition, the courage of the company's management to use debt is related to better company prospects in the future. The decision to finance with debt will cause financial distress which is sensitive to changes in economic conditions. Thus, company management can restructure its capital to reduce the possibility of financial distress. In addition, management needs to pay attention to the level of financial risk associated with the use of debt by the company. This needs to be done, because the use of debt forms the perception of investors that an increase in debt will result in an increase in the financial risk that will be received.

The company's decision to take advantage of profitable investment opportunities in the future can encourage company investment in running its business in the ever-changing business and macroeconomic situation. The amount of investment decisions and the value of the company are determined by the share price. Investor pragmatism on the stock exchange is often a strong argument for the formation of stock market prices. This means that the formation of stock prices is largely influenced by investors' predictions of the company's external macro conditions, particularly macroeconomic conditions which are affected by global economic conditions. External macro conditions like this can be a strong argument for management to consider the external macro conditions of the company in the company's financial decisions. The integration of the company's internal strategy, objectives and policies with predictions of macroeconomic conditions can provide sufficient information for investors. Thus investors can make investment decisions with more comprehensive considerations.

\section{CONCLUSION}

The results of this study indicate that IOS has a significant effect on firm value. That is, IOS as a measure of growth has a direct effect on firm value. Thus, investors respond positively to the company's growth. The significance of the effect of capital structure on IOS shows that the use of debt in financing company investment can be accepted by investors. The use of debt provides a signal that the company has good prospects in the future (signaling theory). The effect of capital structure on firm value occurs when mediated by IOS. This is reinforced by the significant effect of capital structure on firm value. Thus, rationally, investors assess the use of debt to provide a picture of the company's good business prospects in the future.

Estimated economic growth can affect investors' perceptions of management decisions on the use of debt. The investor's response to the decision to use debt can be related to conditions of economic growth. When the stock price has increased, it reflects an increase in the value of the company. This condition indicates the role of economic growth which can strengthen or weaken the influence of capital structure on firm value.

\section{REFERENCES}

[1] R.W. Masulis, "The Impact of Capital Structure Change on Firm Value: Some Estimates," J. Finance, vol. 38, no. 1, pp. 107-126, 1983.

[2] E.F. Fama and K.R. French, "Taxes, Financing Decisions, and Firm Value,” J. Finance, vol. 53, no. 3, pp. 819-843, 1998.

[3] K. Chen, "The Influence of Capital Structure on Company Value with Different Growth Opportunities," Available SSRN 313960, 2002. 
[4] P. Jiraporn and Y. Liu, "Capital Structure, Staggered Boards, and Firm Value," Financ. Anal. J., vol. 64, no. 1, pp. 49-60, 2008.

[5] M. Ikbal and A.D. Sutrisno, "Pengaruh Profitabilitas Dan Kepemilikan Insider Terhadap Nilai Perusahaan Dengan Kebijakan Utang Dan Kebijakan Dividen Sebagai Variabel Intervening (Studi Pada Perusahaan Manufaktur Di Bursa Efek Indonesia)," Simp. Nas. Akunt. XIV Aceh, 2011.

[6] Y. Efni, "Keputusan Investasi, Keputusan Pendanaan Dan Kebijakan Deviden: Pengaruhnya Terhadap Nilai Perusahaan (Studi Pada Sektor Properti Dan Real Estat Di Bursa Efek Indonesia)." Universitas Brawijaya, 2012.
[7] J. LaMasidonda, "Determinan Struktur Modal Dan Dampak Struktur Modal Terhadap Nilai Perusahaan (Studi Pada Perusahaan Manufaktur Di Bursa Efek Indonesia)." Universitas Brawijaya, 2013.

[8] Y. YULIANI, D. Hadiwidjoyo, M. Sudarma, and S. Solimun, "Diversifikasi, Investment Opportunity Set, Dinamika Lingkungan Dan Nilai Perusahaan (Studi Empiris Sektor Manufaktur Di Bursa Efek Indonesia)." Universitas Brawijaya, 2013.

[9] M. Hutchinson and F.A. Gul, "Investment Opportunity Set, Corporate Governance Practices and Firm Performance,” J. Corp. Financ., vol. 10, no. 4, pp. 595-614, 2004.

[10] P.C.R.P.P. Solimun, "Struktural Generalized Structured Componeny Analysis GSCA,” Progr. Stud. Stat. FMIPA Univ. Brawijaya. Malang, 2012 